\title{
Pengaruh Kecerdasan Logika-Matematis, Kecerdasan Intrapersonal Dan Kecerdasan Interpersonal Terhadap Tingkat Pemahaman Pengantar Akuntansi
}

\author{
Rini Adriani Auliana ${ }^{1}$, Endang Sri Andayani ${ }^{2}$ \\ ${ }^{1,2}$ Universitas Negeri Malang \\ email: riniadrianiauliana@yahoo.com
}

\begin{tabular}{ccc}
\hline Diterima & Direvisi & Disetujui \\
$30-12-2020$ & $15-01-2021$ & $26-01-2021$ \\
\hline
\end{tabular}

\begin{abstract}
Understanding introduction of accounting is very important for students department of accounting because it makes easier for studying intermediate accounting and advanced accounting. Students with a low understanding introduction of accounting will be difficult to study advanced accounting. Because of that, students need to have the stronger introduction of accounting for easier students to understands complicated advanced accounting and avoid them from being able to explain comprehensive accounting. One of influence the understanding introduction of accounting is intelligence. This research discusses intelligence based on theory multiple intelligences Howard Gardner. The purpose of this research is (1) the effect of logical-mathematical intelligence on understanding introduction of accounting (2) the effect of intrapersonal intelligence on understanding introduction of accounting (3) the effect of interpersonal intelligence on understanding introduction of accounting. The samples are 170 students with a technique sample simple random sampling. The data was obtained through a test and a questionnaire method. The data analysis used linear regression and the SPSS. As a result of the research is a positive significant correlation between logical-mathematical intelligence on understanding introduction of accounting, nothing significant correlation between intrapersonal intelligence on understanding introduction of accounting and nothing significant correlation between interpersonal intelligence on understanding introduction of accounting.
\end{abstract}

Key Words: Logical, Intrapersonal, Interpersonal

\begin{abstract}
Abstrak - Memahami pengantar akuntansi sangat penting bagi mahasiswa jurusan akuntansi untuk memudahkannya mempelajari mata kuliah akuntansi berikutnya seperti akuntansi keuangan menengah dan akuntansi keuangan lanjutan. Mahasiswa yang memiliki pemahaman pengantar akuntansi rendah akan mengalami kesulitan mempelajari mata kuliah akuntansi lanjutan. Oleh karena itu, pemahaman pengantar akuntansi yang kuat sangat diperlukan untuk mempermudah mahasiswa dalam memahami mata kuliah akuntansi lanjutan yang lebih kompleks dan untuk mencegah ketidakmampuan mahasiswa dalam menjelaskan konsep akuntansi secara luas. Salah satu faktor yang memengaruhi tingkat pemahaman pengantar akuntansi adalah kecerdasan. Penelitian ini membahas kecerdasan berdasarkan teori multiple intelligences Howard Gardner. Tujuan penelitian adalah mengetahui: (1) Pengaruh kecerdasan logika-matematis terhadap tingkat pemahaman pengantar akuntansi; (2) Pengaruh kecerdasan intrapersonal terhadap tingkat pemahaman pengantar akuntansi; dan (3) Pengaruh kecerdasan interpersonal terhadap tingkat pemahaman pengantar akuntansi. Sampel yang digunakan pada penelitian ini berjumlah 170 mahasiswa akuntansi Universitas Negeri Malang dengan teknik pengambilan sampel yaitu simple random sampling. Alat pengumpulan data menggunakan tes dan kuisioner. Teknik analisis data menggunakan analisis regresi berganda dengan bantuan program SPSS. Hasil penelitian menunjukkan bahwa kecerdasan logika-matematis berpengaruh positif signifikan terhadap pemahaman pengantar akuntansi, kecerdasan intrapersonal tidak berpengaruh terhadap pemahaman pengantar akuntansi dan kecerdasan interpersonal tidak berpengaruh terhadap pemahaman pengantar akuntansi.
\end{abstract}

Kata Kunci: Logika, Intrapersonal, Interpersonal

\section{PENDAHULUAN}

Pengantar akuntansi adalah mata kuliah yang memuat materi dasar akuntansi yang digunakan sebagai syarat untuk menempuh mata kuliah akuntansi lanjutan. Mahasiswa yang memiliki pemahaman pengantar akuntansi rendah akan mengalami kesulitan mempelajari mata kuliah akuntansi lanjutan. Oleh karena itu, mahasiswa harus memahami pengantar akuntansi untuk memudahkannya mempelajari mata kuliah akuntansi berikutnya seperti akuntansi keuangan menengah dan akuntansi keuangan lanjutan. Pemahaman pengantar akuntansi yang kuat diperlukan untuk mempermudah 
mahasiswa dalam memahami mata kuliah akuntansi lanjutan yang lebih kompleks (Kusuma \& Bangun, 2011). Berdasarkan beberapa penelitian rata-rata tingkat pemahaman pengantar akuntansi mahasiswa akuntansi adalah 86.31 dengan kriteria baik (SARI, 2013). Sementara itu, penelitian lain menunjukkan bahwa pemahaman pengantar akuntansi mahasiswa masih rendah ditandai dengan persentase ketuntasan mata kuliah pengantar akuntansi sebesar $24,59 \%$ (Rohayati \& Fitrayati, 2015). Perbedaan tingkat pemahaman pengantar akuntansi tersebut bisa disebabkan oleh berbagai faktor. Salah satu faktor yang memengaruhi tingkat pemahaman pengantar akuntansi adalah kecerdasan. Hal ini sesuai dengan penelitian yang yang menghasilkan kecerdasan memengaruhi tingkat pemahaman akuntansi mahasiswa (Riswandi \& Lakoni, 2017). Hasil ini mendukung penelitian yang lain yang menyatakan bahwa faktor-faktor yang dapat memengaruhi tingkat pemahaman akuntansi salah satunya adalah kecerdasan (Suprianto \& Harryoga, 2015). Kecerdasan merupakan faktor yang paling berpengaruh dalam proses belajar peserta didik, karena hal itu menentukan kualitas pemahaman masing-masing peserta didik (Baharuddin \& Wahyuni, 2008).

Kecerdasan menurut Howard Gardner berdasarkan teori Multiple Intelegences adalah kemampuan memecahkan persoalan dan menciptakan suatu produk yang berguna dalam kehidupan (Ula, 2013). Terdapat delapan macam kecerdasan menurut Howard Gardner yaitu kecerdasan linguistik, kecerdasan logis-matematis, kecerdasan interpersonal, kecerdasan intrapersonal, kecerdasan musikal, kecerdasan spasial, kecerdasan kinestetik dan kecerdasan naturalis (Uno \& Kuadrat, 2009). Diantara kecerdasan-kecerdasan tersebut, kecerdasan yang dibutuhkan dalam belajar pengantar akuntansi salah satunya adalah kecerdasan logikamatematis. Hal ini karena dalam belajar akuntansi atau menyelesaikan persoalan akuntansi dibutuhkan kemampuan berhitung dan logika. Belajar pengantar akuntansi melibatkan angka-angka, logika dan perhitungan matematis dalam membuat laporan keuangan atau menyelesaikan permasalahan akuntansi (Sabrina et al., 2009). Pendapat serupa juga dikemukakan oleh Indriani yang menyatakan bahwa salah satu kemampuan dasar yang menjadi syarat untuk belajar akuntansi adalah kemampuan numerik (Wulansari \& Hakim, 2015). Kemampuan yang berkaitan dengan penggunaan angka, bilangan, dan logika secara efektif adalah kemampuan kecerdasan logika-matematis (Ula, 2013). Memahami pengantar akuntansi tidak hanya membutuhkan kecerdasan logika-matematis namun juga membutuhkan kecerdasan intrapersonal. Kecerdasan intrapersonal adalah kemampuan mengenali emosi diri, kemampuan dalam mengelola emosi diri serta kemampuan memotivasi diri (Ula, 2013). Kecerdasan intrapersonal dibutuhkan karena pada proses belajar pengantar akuntansi mahasiswa harus memiliki motivasi yang tinggi agar tidak mudah menyerah ketika menemui kesulitan dalam proses belajar sehingga tercapainya pemahaman akuntansi yang maksimal. Orang dengan kecerdasan intrapersonal yang tinggi mampu berkonsentrasi, sangat disiplin dan memiliki manajemen diri yang baik sehingga dapat membimbing dirinya untuk melakukan hal yang bermamfaat (Ula, 2013). Mahasiswa yang memiliki kecerdasan intrapersonal mampu membuat perencanaan yang baik, mengelola diri agar selalu disiplin dan berkonsentrasi dalam belajar yang tentunya akan lebih memudahkan dalam memahami pelajaran akuntansi sehingga produktivitas dalam belajar dapat meningkat. Selain membutuhkan kecerdasan logika-matematis dan kecerdasan intrapersonal, mahasiswa juga membutuhkan keterampilan dalam berdiskusi atau bekerja sama dengan orang lain agar mendapatkan pemahaman pengantar akuntansi yang baik. Kemampuan memahami dan bekerja sama dengan orang lain merupakan ciri-ciri kecerdasan interpersonal (Ula, 2013). Mahasiswa yang memiliki kemampuan mengenali emosi orang lain, mampu berempati terhadap orang lain, mampu berkomunikasi dan mendengarkan dengan baik akan mudah bersosialisasi dengan orang lain yang membantunya dalam bekerjasama dan berdikusi untuk mendapatkan informasi mengenai pengantar akuntansi sehingga diperoleh pemahaman pengantar akuntansi yang luas.

Beberapa penelitian yang telah dilakukan sebelumnya menunjukkan bahwa kecerdasan logikamatematis berpengaruh positif signifikan terhadap hasil belajar akuntansi mahasiswa sebesar 14,7\% (Pehlİvan \& DURGUT, 2017). Penelitian lainnya menunjukkan bahwa kecerdasan intrapersonal berpengaruh terhadap hasil belajar akuntansi (Beck \& Halim, 2015). Sementara itu terdapat penelitian yang menghasilkan kecerdasan intrapersonal tidak berpengaruh signifikan terhadap tingkat prestasi akademik akuntansi peserta didik (Cabrera \& Fernando, 2009). Penelitian (Beck \& Halim, 2015) dan (Daff et al., 2012) menghasilkan kecerdasan interpersonal berpengaruh positif terhadap pemahaman akuntansi. Adapun hasil penelitian (CHANG \& Fei, 2006) menunjukkan bahwa kecerdasan interpersonal tidak berpengaruh terhadap prestasi belajar akuntansi.

Tujuan dari penelitian ini adalah untuk mengetahui pengaruh kecerdasan logika-matematis, kecerdasan intrapersonal dan kecerdasan interpersonal terhadap pemahaman pengantar akuntansi mahasiswa, sehingga ketika mahasiswa mengetahui bahwa kecerdasan tersebut memiliki pengaruh terhadap pengantar akuntansi mahasiswa bisa mengasah atau menggunakan kecerdasan yang dimiliki secara optimal untuk meningkatkan pemahaman pengantar akuntansi. 


\section{METODE PENELITIAN}

Penelitian ini menggunakan pendekatan kuantitatif dengan jenis penelitian eksplanasi. Penelitian ini menjelaskan pengaruh kecerdasan logika-matematis, kecerdasan intrapersonal dan kecerdasan interpersonal terhadap tingkat pemahaman pengantar akuntansi pada mahasiswa jurusan akuntansi Universitas Negeri Malang. Pada penelitian ini terdapat empat variabel yang terdiri dari tiga variabel bebas dan satu variabel terikat. Adapun hubungan antara variabel bebas dan variabel terikat jika digambarkan sebagai berikut :

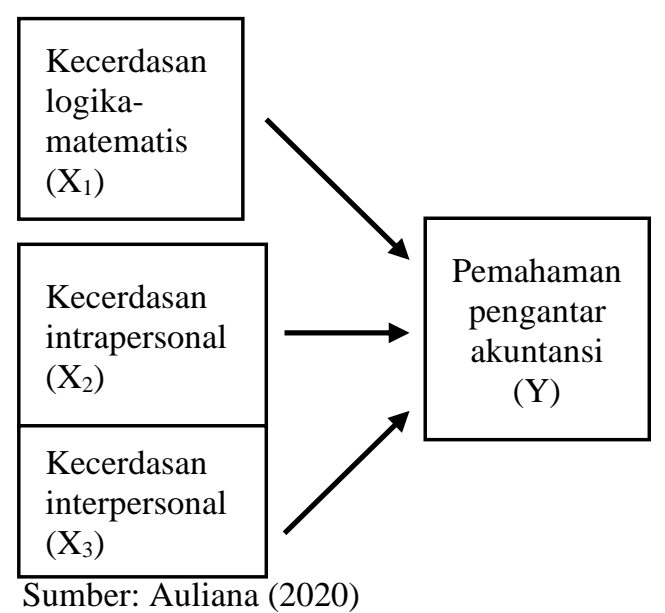

Populasi pada penelitian ini adalah mahasiswa jurusan akuntansi angkatan 2019 di Universitas Negeri Malang sebanyak 294 mahasiswa. Jumlah sampel yang digunakan yaitu 170 mahasiswa dengan teknik pengambilan sampel simple random sampling. Instrumen yang digunakan adalah tes dan kuisioner. Analisis data menggunakan analisis regresi linier berganda dengan bantuan program SPSS.

\section{HASIL DAN PEMBAHASAN}

\section{Tabel 1 Hasil Uji Normalitas}

One Sample Kolmogorov-Smirnov Test

\begin{tabular}{|l|l|r|}
\hline $\mathrm{N}$ & Mean & 170 \\
\cline { 2 - 3 } Normal parameters & Std.dev & .0000000 \\
\hline \multirow{2}{*}{ Most extreme differences } & Absolute & .058 \\
\cline { 2 - 3 } & Positive & .030 \\
\cline { 2 - 3 } & negative & -.058 \\
\hline Kolmogorov-smirnov Z & .761 \\
\hline Asymp sig. (2 tailed) & .609 \\
\hline \\
a. Test distribution is normal \\
Sumber: Hasil Pengolahan SPSS v16
\end{tabular}

Berdasarkan tabel 1 nilai asymp.sig sebesar 0.609 yang berarti nilai asymp.sig > 0.05 (0.609 > 0.05). Berdasarkan hal tersebut dapat disimpulkan bahwa data berdistribusi normal.

\section{Tabel 2 Hasil Uji Heterokedastisitas}

\begin{tabular}{|l|c|}
\hline \multicolumn{1}{|c|}{ Variabel } & Signifikan \\
\hline Kecerdasan logika matematis & 0.443 \\
\hline Kecerdasan intrapersonal & 0.061 \\
\hline Kecerdasan interpersonal & 0.202 \\
\hline
\end{tabular}

Sumber: Hasil Pengolahan SPSS v16

Berdasarkan tabel 2 nilai sig. > 0.05, maka dapat disimpulkan bahwa model regresi tidak terjadi heterokedastisitas.

Tabel 3 Hasil Uji Multikolinearitas

\begin{tabular}{lcc}
\hline \multicolumn{1}{c}{ Variabel } & \multicolumn{2}{c}{ Collinearity Statistics } \\
\cline { 2 - 3 } & Tolerance & VIP \\
\hline $\begin{array}{l}\text { Kecerdasanlogika } \\
\text { matematis }\end{array}$ & 0.958 & 1.044 \\
\hline Kecerdasan intrapersonal & 0.656 & 1.524 \\
\hline Kecerdasan interpersonal & 0.673 & 1.485 \\
\hline Sumber: Hasil Pengolahan SPSS v16
\end{tabular}

Sumber: Hasil Pengolahan SPSS v16

Berdasarkan tabel 3 nilai tolerance $>0.10$ dan nilai VIP $<10.00$, maka dapat disimpulkan bahwa data penelitian tidak terjadi gejala multikolinearitas.

Tabel 4 Hasil Analisis Regresi Linier Berganda

\begin{tabular}{|l|r|r|r|c|}
\hline \multirow{2}{*}{ Model } & \multicolumn{2}{|c|}{$\begin{array}{c}\text { Unstandardized } \\
\text { coefficients }\end{array}$} & Sig. & \\
\cline { 2 - 3 } & $\mathrm{B}$ & $\begin{array}{c}\text { Std. } \\
\text { Error }\end{array}$ & & \\
\hline 1 (constant) & 35.418 & 11.546 & 3.067 & .003 \\
\hline $\begin{array}{l}\text { Kecerdasan } \\
\text { logika } \\
\text { matematis }\end{array}$ & .365 & .065 & 5.588 & .000 \\
\hline $\begin{array}{l}\text { Kecerdasan } \\
\text { intrapersonal }\end{array}$ & .207 & .278 & .0744 & .458 \\
\hline $\begin{array}{l}\text { Kecerdasan } \\
\text { interpersonal }\end{array}$ & -.148 & .248 & -.597 & .551 \\
\hline
\end{tabular}

a. Dependent variable: pemahaman pengantar akuntansi Sumber: Hasil Pengolahan SPSS v16

Berdasarkan tabel 4 diperoleh persamaan regresi linier berganda sebagai berikut

$Y=35.418+0.365 x 1+0.207 x 2-0.148 x 3$

Interpretasi dari koefisien persamaan regresi linier berganda sebagai berikut:

1. Konstanta $(\alpha)$ sebesar 35.418 menunjukkan bahwa jika variabel $\mathrm{X}_{1}, \mathrm{X}_{2}, \mathrm{X}_{3}$ memiliki skor 0 atau konstan maka nilai $\mathrm{Y}$ adalah 35.418

2. Koefisien $X_{1}$ sebesar 0.365 menunjukkan bahwa setiap peningkatan kecerdasan logika matematis akan meningkatkan pemahaman pengantar akuntansi mahasiswa jurusan akuntansi Universitas Negeri Malang angkatan 2019 sebesar 0.365. Hal ini menunjukkan bahwa semakin tinggi kecerdasan logika matematis yang dimiliki oleh mahasiswa jurusan akuntansi maka semakin tinggi pula tingkat pemahaman pengantar akuntansi yang dimiliki. 
3. Koefisien $\mathrm{X}_{2}$ sebesar 0.207 menunjukkan bahwa setiap peningkatan kecerdasan intrapersonal akan meningkatkan pemahaman pengantar akuntansi mahasiswa jurusan akuntansi Universitas Negeri Malang angkatan 2019 sebesar 0.207. Hal ini berarti semakin tinggi kecerdasan intrapersonal yang dimiliki oleh mahasiswa jurusan akuntansi maka semakin tinggi pula tingkat pemahaman pengantar akuntansi yang dimiliki.

4. Koefisien $\mathrm{X}_{3}$ sebesar -0.148 menunjukkan bahwa setiap peningkatan kecerdasan interpersonal akan menurunkan pemahaman pengantar akuntansi mahasiswa jurusan akuntansi Universitas Negeri Malang angkatan 2019 sebesar 0.148. Hal ini menunjukkan bahwa semakin tinggi kecerdasan interpersonal yang dimiliki oleh mahasiswa jurusan akuntansi maka semakin rendah tingkat pemahaman pengantar akuntansi yang dimiliki.

Tabel 5 Hasil Uji F

\begin{tabular}{|l|r|r|}
\hline Model & F & Sig. \\
\hline Regression & 11.41 & .000 \\
& 8 & \\
\hline Residual & & \\
\hline Total & & \\
\hline
\end{tabular}

a. Predictors: (constant), kecerdasan interpersonal,

kecerdasan logika matematis, kecerdasan intrapersonal b. Dependent variable: pemahaman pengantar akuntansi Sumber: Hasil Pengolahan SPSS v16

Berdasarkan tabel 5 menunjukkan bahwa nilai sig. < 0.05 yaitu sebesar $0.000(0.000<0.05)$. Hal ini berarti variasi perubahan nilai pemahaman pengantar akuntansi (Y) dapat dijelaskan oleh variasi perubahan nilai kecerdasan logika-matematis $\left(\mathrm{X}_{1}\right)$, kecerdasan intrapersonal $\left(\mathrm{X}_{2}\right)$ dan kecerdasan interpersonal $\left(\mathrm{X}_{3}\right)$. Dengan demikian dapat disimpulkan bahwa persamaan regresi yang diperoleh baik dan dapat digunakan untuk menaksir nilai pemahaman pengantar akuntansi (Y) pada nilai kecerdasan logikamatematis $\left(\mathrm{X}_{1}\right)$, kecerdasan intrapersonal $\left(\mathrm{X}_{2}\right)$ dan kecerdasan interpersonal $\left(\mathrm{X}_{3}\right)$. Adapun besarnya koefisien determinasi pengaruh kecerdasan logikamatematis $\left(\mathrm{X}_{1}\right)$, kecerdasan intrapersonal $\left(\mathrm{X}_{2}\right)$ dan kecerdasan interpersonal $\left(\mathrm{X}_{3}\right)$ terhadap pemahaman pengantar akuntansi (Y) pada tabel sebagai berikut

Tabel 6 Hasil Koefisien Determinasi

\begin{tabular}{|l|r|r|r|}
\hline Model & R & R square & $\begin{array}{l}\text { Adjusted R } \\
\text { square }\end{array}$ \\
\hline 1 & .414 & .171 & .156 \\
\hline
\end{tabular}

a. Predictors: (constant), kecerdasan interpersonal, kecerdasan logika matematis, kecerdasan intrapersonal b. Dependent variable: pemahaman pengantar akuntansi Sumber: Hasil Pengolahan SPSS v16

Berdasarkan tabel 6 nilai $R$ square sebesar 0.171 yang berarti kecerdasan logika-matematis $\left(\mathrm{X}_{1}\right)$, kecerdasan intrapersonal $\left(\mathrm{X}_{2}\right)$ dan kecerdasan interpersonal $\left(\mathrm{X}_{3}\right)$ mampu menjelaskan pemahaman pengantar akuntansi (Y) sebesar $17.1 \%$ sedangkan sisanya sebesar $82.9 \%$ pemahaman pengantar akuntansi dipengaruhi oleh variabel-variabel lain yang tidak terdapat pada penelitian ini.

\section{Tabel 7 Hasil Uji t}

\begin{tabular}{|l|r|r|r|c|}
\hline \multirow{2}{*}{ Model } & \multicolumn{2}{|c|}{$\begin{array}{c}\text { Unstandardized } \\
\text { coefficients }\end{array}$} & Sig. & \\
\cline { 2 - 4 } & $\mathrm{B}$ & $\begin{array}{c}\text { Std. } \\
\text { Error }\end{array}$ & & \\
\hline 1 (constant) & 35.418 & 11.546 & 3.067 & .003 \\
\hline $\begin{array}{l}\text { Kecerdasan } \\
\text { logika } \\
\text { matematis }\end{array}$ & .365 & .065 & 5.588 & .000 \\
\hline $\begin{array}{l}\text { Kecerdasan } \\
\text { intrapersonal }\end{array}$ & .207 & .278 & .0744 & .458 \\
\hline $\begin{array}{l}\text { Kecerdasan } \\
\text { interpersonal }\end{array}$ & -.148 & .248 & -.597 & .551 \\
\hline
\end{tabular}

Sumber: Hasil Pengolahan SPSS v16

Berdasarkan tabel 7 informasi hasil uji t dijabarkan sebagai berikut:

1. Analisis regresi pengaruh kecerdasan logikamatematis terhadap pemahaman pengantar akuntansi diperoleh hasil nilai $\beta$ sebesar 0.365 , nilai t sebesar 5.588 dengan signifikansi 0.000 kurang dari 5\%. Dengan demikian dapat disimpulkan bahwa hipotesis pertama diterima yang menyatakan kecerdasan logika-matematis berpengaruh positif signifikan terhadap tingkat pemahaman pengantar akuntansi. Hal ini berarti semakin tinggi kecerdasan logika matematis yang dimiliki oleh mahasiswa jurusan akuntansi maka pemahaman pengantar akuntansi yang dimiliki semakin tinggi pula.

Kecerdasan logika-matematis berpengaruh positif dalam meningkatkan pemahaman pengantar akuntansi karena dalam belajar akuntansi atau menyelesaikan persoalan akuntansi dibutuhkan kemampuan berhitung dan logika. Hal ini sesuai dengan pernyataan bahwa belajar pengantar akuntansi melibatkan angka-angka, logika dan perhitungan matematis dalam membuat laporan keuangan atau menyelesaikan permasalahan akuntansi (Sabrina et al., 2009). Pendapat lain dikemukakan oleh Indriani yang menyatakan bahwa salah satu kemampuan dasar yang menjadi syarat utama dalam belajar akuntansi adalah kemampuan numerik karena belajar akuntansi berhubungan dengan angka-angka (Wulansari \& Hakim, 2015). Oleh karena itu kemampuan numerik merupakan salah satu faktor yang mempengaruhi keberhasilan belajar akuntansi. Pendapat tersebut sejalan dengan teori Multiple Intelligences Howard Gardner yaitu kemampuan yang berkaitan dengan penggunaan angka, bilangan, dan logika secara efektif yang banyak dimiliki oleh matematikawan dan akuntan adalah kemampuan kecerdasan logika-matematis (Ula, 2013). Sementara itu, diketahui bahwa mahasiswa 
jurusan akuntansi yang berasal dari SMK memiliki rata-rata tingkat kecerdasan logika matematis lebih tinggi daripada yang berasal dari SMA. Namun, tingkat kecerdasan logika matematis mahasiswa yang berasal dari SMA lebih beragam daripada yang berasal dari SMK. Adapun mahasiswa perempuan memiliki rata-rata kecerdasan logika-matematis lebih tinggi daripada mahasiswa laki-laki. Namun, tingkat kecerdasan logika-matematis yang dimiliki oleh mahasiswa laki-laki lebih beragam daripada mahasiswa perempuan.

Penelitian ini memperkuat hasil penelitian (Armeliza, 2018) dan (Wulansari \& Hakim, 2015) yang menyatakan bahwa semakin tinggi kecerdasan logika-matematis yang dimiliki mahasiswa, maka tingkat pemahaman akuntansi yang dimiliki juga semakin meningkat. Bahkan kecerdasan logika matematis berpengaruh positif dan paling relevan diantara ketujuh kecerdasan lainnya terhadap hasil ujian tengah semester akuntansi mahasiswa (CHANG \& Fei, 2006). Berdasarkan hal tersebut, mahasiswa yang memiliki kecerdasan logika matematis tinggi lebih mudah memahami pengantar akuntansi dengan cepat dan memiliki pemahaman pengantar akuntansi yang baik sedangkan mahasiswa yang tidak memiliki kecerdasan logika matematis akan kesulitan dalam memahami pengantar akuntansi. Hasil penelitian ini sejalan dengan penelitian yang dilakukan oleh (Pehlìvan \& DURGUT, 2017) menunjukkan bahwa kecerdasan logikamatematis berpengaruh positif terhadap hasil belajar akuntansi mahasiswa dengan persentase sebesar $(\mathrm{R} 2=14.7 \%)$. Terdapat penelitian lain dengan hasil serupa yaitu kecerdasan logis matematis berpengaruh positif terhadap prestasi akademik akuntansi dengan persentase sebesar 4.65\% (Cabrera \& Fernando, 2009), sedangkan penelitian ini menunjukkan bahwa kecerdasan logika matematis berpengaruh positif signifikan terhadap pemahaman pengantar akuntansi sebesar $(\mathrm{R} 2=17,1 \%)$.

2. Analisis regresi pengaruh kecerdasan intrapersonal terhadap pemahaman pengantar akuntansi diperoleh hasil nilai $\beta$ sebesar 0.207 , nilai $\mathrm{t}$ sebesar 0.744 dengan signifikansi 0.458 lebih dari 5\%. Dengan demikian dapat disimpulkan bahwa hipotesis kedua ditolak yaitu kecerdasan intrapersonal berpengaruh positif signifikan terhadap tingkat pemahaman pengantar akuntansi. Artinya, tingkat pemahaman pengantar akuntansi tidak dipengaruhi oleh tinggi rendahnya kecerdasan intrapersonal yang dimiliki oleh mahasiswa jurusan akuntansi. Hasil tersebut tidak sejalan dengan pendapat yang menyatakan mahasiswa akuntansi akan mendapatkan banyak mamfaat apabila meningkatkan keterampilan intrapersonalnya (Daff et al., 2012). Hasil ini juga tidak sesuai dengan teori multiple intelligences Howard Gardner yaitu kecerdasan intrapersonal adalah kemampuan mengenali emosi diri, kemampuan dalam mengelola emosi diri serta kemampuan memotivasi diri (Ula, 2013).

Orang dengan kecerdasan intrapersonal memiliki motivasi yang tinggi agar tidak mudah menyerah ketika menemui kesulitan dalam belajar sehingga tercapainya pemahaman akuntansi yang maksimal. Mahasiswa yang memiliki kecerdasan intrapersonal mampu membuat perencanaan yang baik, mengenali emosi diri dan mengelola diri agar selalu disiplin dan berkonsentrasi dalam belajar yang tentunya akan lebih memudahkan dalam memahami pelajaran akuntansi sehingga produktivitas dalam belajar dapat meningkat. Namun, hal tersebut tidak sesuai dengan hasil penelitian ini yang menyatakan bahwa kecerdasan intrapersonal tidak memiliki pengaruh terhadap pemahaman pengantar akuntansi. Artinya meskipun mahasiswa memiliki motivasi yang tinggi, mandiri, mampu mengelola emosi diri hal tersebut tidak memengaruhi tingkat pemahaman pengantar akuntansi yang dimiliki. Oleh karena itu, kecerdasan intrapersonal yang tinggi tidak dapat membuat pemahaman pengantar akuntansi meningkat. Sementara itu, diketahui bahwa mahasiswa jurusan akuntansi yang berasal dari SMA memiliki rata-rata kecerdasan intrapersonal lebih tinggi daripada yang berasal dari SMK. Namun, mahasiswa jurusan akuntansi yang berasal dari SMK memiliki kecerdasan intrapersonal yang lebih beragam daripada yang berasal dari SMA, karena nilai yang lebih beragam tersebut tingkat kesenjangan kecerdasan intrapersonal mahasiswa jurusan akuntansi dari SMK lebih besar daripada SMA. Adapun rata-rata kecerdasan intrapersonal mahasiswa laki-laki lebih tinggi daripada mahasiswa perempuan. Namun, kecerdasan intrapersonal yang dimiliki mahasiswa laki-laki dan mahasiswa perempuan persebaran datanya hampir seragam.

Hasil penelitian ini tidak sejalan dengan penelitian (CHANG \& Fei, 2006) dan (Beck \& Halim, 2015) yang menunjukkan bahwa kecerdasan intrapersonal berpengaruh terhadap prestasi belajar akuntansi mahasiswa. Namun, hasil ini sejalan dengan penelitian (Cabrera \& Fernando, 2009) menghasilkan kecerdasan intrapersonal tidak berpengaruh signifikan terhadap tingkat prestasi akademik akuntansi peserta didik. Penelitian ini tidak dapat menemukan pengaruh antara kecerdasan intrapersonal terhadap pemahaman pengantar akuntansi disebabkan oleh beberapa faktor seperti mahasiswa dengan kecerdasan intrapersonal memiliki sifat independen sehingga cenderung senang mengambil keputusan secara mandiri, hal ini menyebabkan ketika mahasiswa memiliki 
kesulitan memahami pengantar akuntansi ia memilih untuk menyelesaikan kesulitan yang dialami sendiri yang dapat menyebabkan hasil yang diperoleh menjadi keliru. Hal tersebut didukung oleh pernyataan bahwa siswa yang mempunyai sikap mandiri dan percaya diri mengerjakan soal tanpa analisa lebih mendalam yang menyebabkan hasil yang diperoleh tidak sesuai harapan (Mahmud \& Amaliyah, 2017). Selain itu, mahasiswa yang memiliki pengenalan diri dan pengendalian diri cenderung idealis dan sulit menerima pendapat karena merasa dirinya sudah melakukan hal yang sesuai dengan kemampuannya. Hal ini diperkuat oleh penelitian yang menyatakan mahasiswa yang memiliki pengenalan diri namun hanya berfokus pada kelemahan dirinya akan mengakibatkan mahasiswa malas belajar dan menurunkan tingkat pemahamannya (Rahayu et al., 2007). Selain itu mahasiswa yang memiliki motivasi namun tidak diikuti oleh kepercayaan diri akan cenderung pesimis sehingga tidak dapat meningkatkan pemahaman akuntansi. Mahasiswa yang memiliki motivasi namun tidak memiliki kepercayaan diri akan merasa malas untuk mencoba lagi jika pernah gagal karena merasa diri kurang memiliki kemampuan (Rahayu et al., 2007).

3. Analisis regresi pengaruh kecerdasan interpersonal terhadap pemahaman pengantar akuntansi diperoleh hasil nilai $\beta$ sebesar -0.148 , nilai t sebesar -0.597 dengan signifikansi 0.551 lebih dari 5\%. Dengan demikian dapat disimpulkan bahwa hipotesis ketiga ditolak yang menyatakan kecerdasan interpersonal berpengaruh positif signifikan terhadap tingkat pemahaman pengantar akuntansi. Artinya, tingkat pemahaman pengantar akuntansi tidak dipengaruhi oleh tinggi rendahnya kecerdasan interpersonal yang dimiliki oleh mahasiswa jurusan akuntansi. Hasil penelitian ini tidak sesuai dengan pernyataan peningkatan pemahaman mahasiswa saat ini melibatkan interaksi antar mahasiswa untuk mencapai pemahaman dalam belajar sehingga dibutuhkan kerja sama, diskusi dan interaksi sosial lainnya (Sari \& Prastati, 2016). Kemampuan memahami dan bekerja sama dengan orang lain merupakan ciri-ciri kecerdasan interpersonal (Ula, 2013). Hasil penelitian ini juga tidak sejalan dengan teori multiple intelligences Howard Gardner yang menyatakan seseorang dengan kecerdasan interpersonal akan memiliki keterampilan dalam berdiskusi atau bekerja sama dengan orang lain sehingga diperoleh hasil belajar yang baik. Oleh karena itu, mahasiswa yang memiliki kemampuan memahami orang lain, kemampuan berkomunikasi dan mendengarkan orang lain yang dapat memudahkan dalam berdiskusi dan bekerja sama untuk membantu mendapatkan informasi yang memudahkannya dalam proses belajar memahami pengantar akuntansi lebih luas tidak dapat meningkatkan pemahaman pengantar akuntansi yang dimiliki oleh mahasiswa. Sementara itu, rata-rata tingkat kecerdasan interpersonal mahasiswa jurusan akuntansi yang berasal dari SMA dan SMK tidak terdapat perbedaan yang yang besar. Namun, tingkat keragaman kecerdasan interpersonal yang dimiliki oleh mahasiswa jurusan akuntansi yang berasal dari SMK lebih beragam daripada SMA. Dengan demikian, mahasiswa jurusan akuntansi yang berasal dari SMK memiliki kesenjangan kecerdasan interpersonal yang lebih besar daripada yang berasal dari SMA. Adapun, rata-rata kecerdasan interpersonal mahasiswa perempuan lebih tinggi daripada mahasiswa lakilaki. Namun, tingkat kecerdasan interpersonal mahasiswa laki-laki lebih beragam daripada mahasiswa perempuan

Hasil penelitian ini memperkuat hasil penelitian (CHANG \& Fei, 2006) dan (Cabrera \& Fernando, 2009) yang menunjukkan bahwa kecerdasan interpersonal tidak berpengaruh terhadap prestasi belajar akuntansi. Namun penelitian ini tidak sejalan dengan hasil penelitian (Beck \& Halim, 2015), (Daff et al., 2012) dan (Sari \& Prastati, 2016) yang menghasilkan kecerdasan interpersonal berpengaruh positif terhadap pemahaman akuntansi. Pengaruh antara kecerdasan interpersonal dan pemahaman pengantar akuntansi tidak ditemukan disebabkan karena ketika mahasiswa berdiskusi hal-hal yang dibahas lebih banyak diluar materi pengantar akuntansi sehingga pemahaman yang dimiliki tidak meningkat. Hal ini diperkuat oleh penelitian yang menyatakan bahwa kecerdasan sosial tidak berpengaruh terhadap pemahaman akuntansi karena ketika mahasiswa bersosialisasi dan berkumpul, lebih mementingkan memperbanyak teman dan membahas hal-hal diluar mata kuliah akuntansi sehingga tidak mempengaruhi pemahaman akuntansinya (Anam \& Ardillah, 2016). Selain itu tidak ada hubungan yang signifikan antara keterampilan sosial dengan kemampuan mahasiswa dalam pemahaman akuntansi karena ukuran pemahaman akuntansi pada umumnya merupakan ukuran kognitif yang tidak dapat diukur dengan kemampuan keterampilan sosial mahasiswa (Horri \& Handayani, 2018)

\section{KESIMPULAN}

Berdasarkan hasil penelitian dan pembahasan, kesimpulan dari penelitian ini adalah Kecerdasan logika-matematis memiliki pengaruh positif signifikan terhadap tingkat pemahaman pengantar akuntansi mahasiswa jurusan akuntansi Universitas Negeri Malang angkatan 2019. Berdasarkan hal tersebut, indikator kecerdasan logika-matematis yaitu 
kemampuan berhitung, berpikir logis, pemecahan masalah dan ketajaman pola serta hubungan mempengaruhi tingkat pemahaman pengantar akuntansi mahasiswa. Hal ini karena kemampuan numerik, berpikir logis dan pemecahan masalah merupakan kemampuan dasar yang diperlukan untuk belajar pengantar akuntansi dan menyelesaikan soalsoal pengantar akuntansi. Kecerdasan intrapersonal tidak berpengaruh terhadap tingkat pemahaman pengantar akuntansi mahasiswa jurusan akuntansi Universitas Negeri Malang angkatan 2019. Hasil penelitian ini menunjukkan bahwa indikator kecerdasan intrapersonal yaitu kesadaran diri emosional, kemampuan mengelola emosi diri, memotivasi diri, keasertifan dan mandiri tidak memengaruhi tingkat pemahaman pengantar akuntansi. Kecerdasan interpersonal tidak berpengaruh terhadap tingkat pemahaman pengantar akuntansi mahasiswa jurusan akuntansi Universitas Negeri Malang angkatan 2019. Hasil penelitian ini menunjukkan bahwa indikator kecerdasan interpersonal yaitu mengenali emosi orang lain, sifat empati, mengetahui etika social, kemampuan berkomunikasi dan mendengarkan orang lain yang dapat membantu mempermudah bekerjasama dan bersosialisasi dengan orang lain tidak mempengaruhi pemahaman pengantar akuntansi yang dimiliki oleh mahasiswa. Adapun Peneliti diharapkan dapat menambahkan variabel independen ataupun variabel intervening yang dapat mempengaruhi pemahaman akuntansi mahasiswa (Wulansari \& Hakim, 2015). Selain itu, peneliti lain direkomendasikan untuk melakukan penelitian mengenai prediksi nilai atau tingkat kelulusan mahasiswa berdasarkan tingkat kecerdasan yang dimilikinya (Cabrera \& Fernando, 2009)

\section{REFERENSI}

Anam, H., \& Ardillah, L. (2016). Pengaruh Kecerdasan Emosional , Kecerdasan Intelektual , Kecerdasan Spiritual Dan Kecerdasan Sosial Terhadap Pemahaman Akuntansi. Jurnal Sains Terapan, 2(1), 40-47.

Armeliza, D. (2018). The Influence Of Achievement Motivation, Mathematical Logical Intelligence, And Self-Efficacy Towards The Level Of Accounting Comprehension. 16(September), 109-115

Baharuddin, H., \& Wahyuni, E. (2008). Teori Belajar Dan Pembelajaran. Ar-Ruzz Media.

Beck, J. E., \& Halim, H. (2015). Undergraduate Internships In Accounting : What And How Do Singapore Interns Learn From Experience? Undergraduate Internships In Accounting: What And How Do Singapore Interns Learn From Experience? Accounting Education, 9284(December).
Https://Doi.Org/10.1080/09639280701220277

Cabrera, J. P., \& Fernando, G. V. (2009). Multiple Intelligences As Predictor Of Academic Performance In Accounting : Evidence From A Private University In The Phlippines. 1-16.

Chang, \& Fei, C. (2006). Teaching Accounting To Learners With Diverse Intelligence. Apera Conference 2006, November.

Daff, L., Lange, P. De, \& Jackling, B. (2012). A Comparison Of Generic Skills And Emotional Intelligence In Accounting Education. 27(3), 627-645. Https://Doi.Org/10.2308/Iace-50145

Horri, M., \& Handayani, A. E. (2018). Pengaruh Kecerdasan Emosional Terhadap Tingkat Pemahaman Akuntansi Pada Mahasiswa Akuntansi Di Universitas Dr. Soetomo. Jurnal Analisa Akuntansi Dan Perpajakan, 2(September), 86-98.

Kusuma, B. H., \& Bangun, N. (2011). Analisis Pemahaman Mahasiswa Akuntansi Terhadap Konsep Aset, Kewajiban, Dan Ekuitas. Jurnal Bisnis Dan Akuntansi, 13(3), 183-194.

Mahmud, N., \& Amaliyah, R. (2017). Pengaruh Kecerdasan Intrapersonal Terhadap Prestasi Belajar Matematika Siswa Kelas Xi Mipa Sma Negeri Di Kabupaten Polewali Mandar. 327330.

Pehlivan, A., \& Durgut, M. (2017). The Effect Of Logical-Mathematical Intelligence On Financial Accounting Achievement According To Multiple Intelligence Theory. Journal of Education \& Social Policy, 4(3), 132-139.

Rahayu, S., Anna, Y. D., \& Said, L. (2007). Pengaruh Kecerdasan Emosional Terhadap Tingkat Pemahaman Akuntansi. 9(4), 1668-1679.

Riswandi, P., \& Lakoni, I. (2017). Pengaruh Kecerdasan Emosional , Kecerdasan Spritual Dan Kecerdasan Intelektual Terhadap Pemahaman Mata Kuliah Pengantar Akuntansi Dengan Perilaku Belajar Sebagai Variabel Moderasi Di Ptn Dan Pts Kota Bengkulu Pendahuluan Mata Kuliah Akuntansi Diperkenalka. $1(2)$. Https://Doi.Org/Https://Doi.Org/10.21070/Jas. V1i2.972 July

Rohayati, S., \& Fitrayati, D. (2015). Peningkatan Hasil Belajar Mahasiswa Melalui Direct Instructional Pada Matakuliah Pengantar Akuntansi. 236-250.

Sabrina, N., Welly, \& Dayamasari, P. (2009). FaktorFaktor Yang Mempengaruhi Pemahaman 
Mahasiswa Program Studi Akuntansi Tahun 2009 Terhadap Mata Kuliah Pengantar Akuntansi Pada Perguran Tinggi Swasta Di Seberang Ulu Palembang.

Sari, D. F., \& Prastati, S. D. (2016). Pengaruh Kecerdasan Interpersonal Terhadap Sebagai Variabel Intervening Pada Siswa Jurusan Akuntansi.

Sari, Y. K. (2013). Pengaruh Pengendalian Diri Dan Perilaku Belajar Terhadap Tingkat Pemahaman Pengantar Akuntansi.

Suprianto, E., \& Harryoga, S. (2015). Faktor-Faktor Penentu Tingkat Pemahaman. Xviii(3), 75-90.
Ula, S. (2013). Revolusi Belajar. Ar-Ruzz Media.

Uno, H., \& Kuadrat, M. (2009). Mengelola Kecerdasan Dalam Pembelajaran. Pt Bumi Aksara.

Wulansari, M., \& Hakim, L. (2015). Pengaruh Kecerdasan Logis-Matemtaakuntansi , Dan Minat Belajar Terhadap Tingkat Pemahaman Akuntansi. Jurnal Fakultas Ekonomi Dan Bisnis, 1-9. 